\title{
AMPEROMETRIC BIOSENSOR FOR PESTICIDE METHAMIDOPHOS ASSAY
}

\author{
Miroslav Pohanka ${ }^{1}$, Kamil Kuča ${ }^{2,3}$, Daniel Jun ${ }^{2,3}$ \\ Center of Biological Defense, Těchonín, Central Military Institute of Health, Czech Republic ${ }^{1}$; University of Defence, \\ Faculty of Military Health Sciences Hradec Králové, Czech Republic: Center of Advanced Studies ${ }^{2}$, Department of \\ Toxicology 3
}

Summary: Amperometric biosensor based on enzyme acetylcholinesterase (AChE; EC 3.1.1.7) was tested for pesticide methamidophos assay. Biosensor consists from four screen printed platinum electrodes on ceramic strip. AChE was physically adsorbed onto the electrode surface. The measuring principle was based on the inhibition of AChE activity in the presence of methamidophos. The proposed method limit of detection was $2.45 \mathrm{nM}$, responding to 3.46 pg of methamidophos detected absolutely when we consider the sample volume.

Key words: Methamidophos; Pesticide; Amperometric; Electrochemical; Biosensor; Acetylcholinesterase; Assay

\section{Introduction}

Organophosphorous pesticides are a large group of compounds exerting an important role in different human activities. Their common toxic effect is based on the inhibition of enzymes with cholinesterase activity: acetylcholinesterase (AChE; EC 3.1.1.7) and butyrylcholinesterase (BChE; EC 3.1.1.8) that play important roles in human and animal bodies (10). Their mechanism of inhibition is based on phosphorylation of the physiologically active serine hydroxyl group in the active centre of the enzyme (8). Poisoning by organophosphates leads to malfunction of the cholinergic nervous system. Although poisoning could be a serious fulmination, there are several ways of treating it. The first one is based on the physiological suppression of the cholinergic crisis; drugs with anticholinergic activity such as atropine are convenient for this purpose $(1,7)$. Another method of treatment is based on reactivators. For these purposes a large group of oximes is suitable, such as obidoxime, pralidoxime, and HI-6 $(2,8,9)$.

Methamidophos ((RS)-O,S-dimethyl phosphoramidothioate) is one of the currently used pesticides; it is commercially available under product names such as Monitor, Nitofol, Tamaron, Swipe, Nuratron, Vetaron, Filitox, Patrole, and Tamanox for suppression of chewing and sucking insect populations. Methamidophos is able to affect AChE in the same manner such as other organophosphorus pesticides (5). Methamidophos exerts high toxicity towards large groups of animals. Per oral $\mathrm{LD}_{50}$ value ranges from 10 (rabbits) to $50 \mathrm{mg} / \mathrm{kg}$ (guinea pigs); methamidophos intake by humans leads to paralysis of limbs and respiratory muscles within four days after exposure $(16,17)$.
One of the important tasks in suppressing the harmful effects of methamidophos is timely detection. Widely available techniques are based on mass spectrometry and/or liquid chromatography $(6,15)$. Biosensors could be an alternative to the classical analytical methods. It was described as a useable tool for the analysis of different analytes, including microorganisms (13) and toxic compounds (11, 14). The suitability of biosensors for organophosphates and carbamates detection was extensively reviewed (18). Biosensors harboring cholinesterase attached to the electrode surface are the most typical; an assay is based on a decrease in cholinesterase activity due to inhibition by analyte (organophosphate) during the measuring procedure. Different electrodes and immobilization techniques can be applied. A platinum electrode covered with a composite, including $\mathrm{AChE}$ and graphite, cobalt phthalocyanine and acetylcellulose (20), an adsorbed mixture of cholinesterase, glutaraldehyde and albumin onto a screen printed platinum surface $(12,19)$, were found to be convenient. Furthermore, graphite rods and nylon fibres were also considered suitable as a biosensor with cholinesterase construction $(3,4,21)$. The presented study is focused on the preparation and performance of amperometric biosensor for methamidophos assay. The suitability of the developed biosensor for assay will be the object of discussion.

\section{Material and methods}

\section{Chemicals}

Lyophilized human recombinant AChE, acetylthiocholine chloride $(\mathrm{ATChCl})$, glutaraldehyde and methamidophos (analytical standard, $98.4 \%$ ) were purchased from 
Sigma-Aldrich. Deionized water was obtained by Millipore system. All other chemicals were in the standard analytical quality.

\section{Immobilization procedure}

$\mathrm{AChE}$ was suspended into deionized water: final activity $0.05 \mathrm{nkat} / \mu 1.1 \mu \mathrm{l}$ of AChE solution was injected on one out of every four platinum electrodes printed onto ceramic strip (BVT, Brno, Czech Republic) and the solution was allowed to dry at the laboratory temperature. In the second step, a whole ceramic strip was placed into the chamber filled with glutaraldehyde vapor and $1 \mu \mathrm{l}$ of AChE solution per electrode was applied again and allowed to dry (about half an hour). Finally, the created biosensor was gently washed with phosphate buffered saline (PBS).

\section{Measuring setup and data processing}

The biosensor was dipped into a reaction cell (polypropylene, shaped as flat bottom cylinder with maximal volume $2 \mathrm{ml}$ ) filled with $990 \mu \mathrm{l}$ of reaction medium $(1 \mathrm{mM}$ ATChCl in PBS). The reaction cell was stirred with a teflon-coated magnetic agitator (length $5 \mathrm{~mm}$ ). A silver wire covered by silver chloride was used as a reference electrode. The applied potential was set on $+450 \mathrm{mV}$ for oxidation of the forming thiocholine (followed parameter). The current $\left(\mathrm{i}_{0}\right)$ was measured by the amperometric detector MEB (MultiLab, Brno, Czech Republic). The background current $\left(i_{b}\right)$ was measured in the same manner as $i_{0}$; however, the biosensor was displaced by a sensor (strip without immobilized AChE). The current after inhibition $\left(i_{i}\right)$ was obtained when $10 \mu \mathrm{l}$ of methamidophos solution in water per one electrode was applied for $10 \mathrm{~min}$. Incubation with methamidophos was realized out of the reaction chamber. After that, the biosensor was dipped into the reaction chamber and $i_{i}$ was read. The percent of inhibition (I) was calculated in the following way:

$$
I=\left(1-\frac{i_{i}-i_{b}}{i_{0}-i_{b}}\right) \times 100
$$

\section{Results and discussion}

The biosensor was prepared as described above. The $\mathrm{i}_{0}$ was evaluated as $212 \mathrm{nA}$ during the first observations. The sensor strip without the immobilized AChE tested in the same manner provided the signal $76 \mathrm{nA}$. Methamidophos was dilluted with deionized water into five calibration concentrations: $1 ; 10 ; 100 ; 1000$ and 10000 nM. Every concentration was assayed by the biosensor and the I parameter was calculated according equation 1 . The calibration curve (Fig. 1) is presented in the form of I vs. $\log \mathrm{M}$, where $\log \mathrm{M}$ is the logarithm of methamidophos concentration in nM.

PBS applied in the very same manner as methamidophos was used for blank purposes. No relevant false positive result was obtained from blank application. The limit of

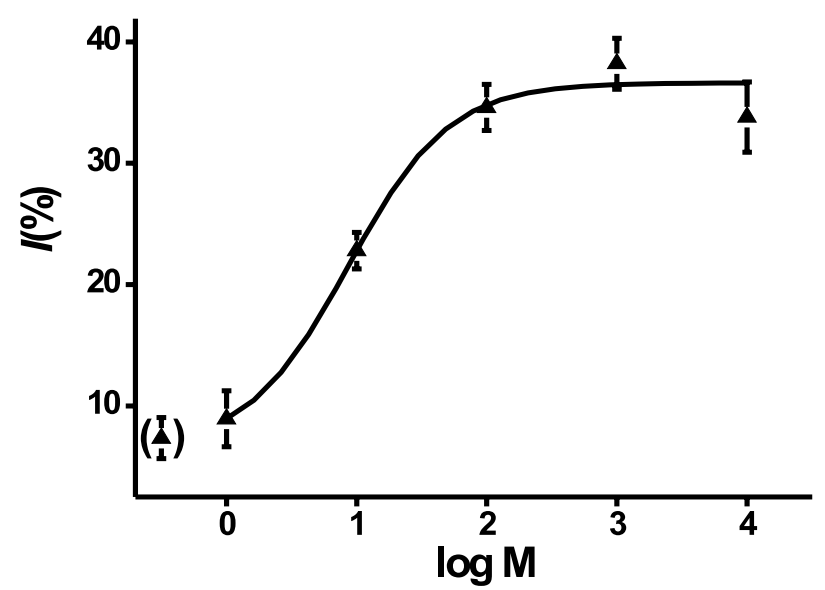

Fig. 1: Calibration curve for methamidophos. The x-axis $(\log \mathrm{M})$ value means the logarithm of methamidophos concentration in nanomoles. The y-axis $[I(\%)]$ value means the percent of inhibition according to equation 1 . The blank is expressed as a value in brackets. Error bars indicate standard deviation $(n=3)$.

Tab. 1: The most important analytical parameter expressions.

\begin{tabular}{|l|c|}
\hline Limit of detection (molar scale) & $2.45 \mathrm{nM}$ \\
\hline Limit of detection (parts per million scale) & $0.0035 \mathrm{ppm}$ \\
\hline Limit of detection absolutely & $3.46 \mathrm{pg}$ \\
\hline Needed sample volume per electrode & $10 \mu \mathrm{l}$ \\
\hline Maximal time per one measuring cycle & $20 \mathrm{~min}$ \\
\hline
\end{tabular}

detection (LOD) was the point at the calibration scale equal to the triplicate of the blank standard deviation $(\mathrm{S} / \mathrm{N}=3)$; the calculation found LOD $2.45 \mathrm{nM}$ responding to absolute $3.46 \mathrm{pg}$ when we considered the sample volume of $10 \mu 1$. The calibration allows for quantification of the measured methamidophos up to a concentration $1 \mu \mathrm{M}$. The most important analytical parameters are summarized in Tab. 1.

The obtained results point to the feasibility of the biosensors. In particular, biosensors seem to be suitable as a low cost device for methamidophos analysis and in this way diminish fulmination of methamidophos as residuum in the environment. The U.S. Environmental Protection Agency (EPA) on its website proposes decreasing the tolerance limit for methamidophos as residuum in vegetables from 1 to $0.5 \mathrm{ppm}$ (http://www.epa.gov/fedrgstr/EPA-PEST/ 2007/May/Day-23/p2561.htm). The LOD of developed biosensor is $0.0035 \mathrm{ppm}$, so not only the original but also the EPA proposed tolerance limit can be detected with this arrangement.

\section{Conclusions}

The presented work focused on the development of a simple method for low level methamidophos concentra- 
tion detection. The proposed biosensor is able to detect methamidophos in concentrations approximately three hundred times lower than admissible as residuum. We are encouraged by the obtained results and we expected further complex studies focused on the testing of biosensor applicability for pesticides assay.

\section{Acknowledgements}

The support of the Ministry of Industry and Trade of the Czech Republic for the Project No.2A-1TP1/007 is gratefully acknowledged.

\section{References}

1. Bajgar J. Organophosphates/nerve agent poisoning: mechanism of action, diagnosis, prophylaxis and treatment. Adv Clin Chem 2004;38:151-216.

2. Bajgar J, Fusek J, Kuča K, Bartošová L, Jun D. Treatment of organophosphate intoxication using cholinesterase reactivators: facts and fiction. Mini Rev Med Chem 2007;7:461-6.

3. Ciucu A, Ciucu C. Organic phase amperometric biosensor for detection of pesticides. 2002;7:667-6.

4. Gulla KC, Gouda MD, Thakur MS, Karanth NG. Reactivation of immobilized acetylcholinesterae in an amperometric biosensor for organophosphorus pesticide. Biochim Biophys Acta 2002;1597:133-9.

5. Hussain MA. Anticholines-terasse properties of methamidophos and acephate in insects and mammals. Bull Environ Contam Toxicol 1987;38:131-8.

6. Inoue S, Saito $\mathrm{T}$, Mase $\mathrm{H}$ et al. Rapid simultaneous determination for organophosphorus pesticides in human serum by LC-MS. J Pharm Biomed Anal 2007;44:258:264
7. Kassa J. Review of oximes in the antidotal treatment of poisoning by organophosphorus nerve agents. J Toxicol Clin Toxicol 2002;6:803-16.

8. Kuča K, Jun D, Musilek K. Structural requirements of acetylcholinesterase reactivators. Mini Rev Med Chem 2006;6:269-77.

9. Kuča K, Jun D, Bajgar J. Currently used cholinesterase reactivators against nerve agent intoxication: comparison of their effectivity in vitro. Drug Chem Toxicol 2007;30:31-40.

10. Patočka J, Kuča K, Jun D. Acetylcholinesterase and butyrylcholinesterse - important enzymes of human body. Acta Medica 2004;47:215-28.

11. Pohanka M, Jun D, Kuča K. Mycotoxin assays using biosensor technology: A review. Drug Chem Toxicol 2007:30:253-61.

12. Pohanka M, Jun D, Kuča K. Amperometric biosensor for evaluation of competitive cholinesterase inhibition by the reactivator HI-6. Anal Lett In press.

13. Pohanka M, Skládal P, Kroča M. Biosensors for biological warfare agent detection. Def Sci J 2007;57:185-93.

14. Pohanka M, Zbořil P. Amperometric biosensor for D-lactate assay. Food Technol Biotechnol In press.

15. Pozo OJ, Barreda M, Sancho JV et al. Multiresidue pesticide analysis of fruits by ultra-performance liquid chromaography tandem mass spectrometry. Anal Bioanal Chem In press.

16. Senanayake N, Johnson MK. Acute polyneuropathy after poisoning by a new organophosphate isecticide. N Engl J Med 1982;306:155-7.

17. Senanayake N, Karalliedde L. Neurotoxic effects of organophospharus insecticides. N Engl J Med 1987;316:761-3.

18. Skládal P. Biosensor based on cholinesterase for detection of pesticides. Food Technol Biotechnol 1996;34:43-9.

19. Skládal P, Krejčí J. Performance of the amperometric biosensor with immobilized butyrylcholinesterase in organic solvents. Collect Czech Chem Commun 1996; 61:985-91.

20. Skládal P, Nunes GS, Yamanaka H, Ribeiro ML. Detection of carbamate pesticides in vegetable samples using cholinesterase-based biosensors. Electroanalysis 1997;9:1083-7.

21. Sotiropoulou S, Chaniotakis NA. Lowereing the detection of the acetylcholinesterase biosensor using a nanoporous carbon matrix. Anal Chim Acta 2005; 530:199-204.

\section{Corresponding author:}

RNDr. Miroslav Pohanka, Center of Biological Defense, 56166 Těchonín, Czech Republic, e-mail: rau@atlas.cz 